\title{
CATASTROPHIC CHANGES IN VEGETATION ca. 8.2 ka \& LAKE SETTLEMENTS IN THE VOLGA-OKA REGION (based on the site Zamostje 2)
}

The most important changes in the economy and material culture in foraging societies of the Eastern Europe forest zone on the eve of the spread of ceramic production coincided with the 8.2 ka Cold Event and its consequences. We consider these changes in the local example of the site Zamostje 2 located in Volga-Oka region, using results of long-time multidisciplinary research. Findings of our archaeological and paleoecological studies and comparison with regional data draw a picture of local changes in the context of ecological instability and discontinuity of material culture traditions in the second half of the $7^{\text {th }}-$ beginning of the $6^{\text {th }}$ mil. Cal BC.

Keywords: 8.2 ka Cold Event, paleoenvironmental changes, Upper Volga region, Late Mesolithic, last huntergatherer societies, lake settlement Zamostje 2

\section{INTRODUCTION}

Climatic and ecological changes have always directly or indirectly influenced the economic and social life of prehistoric communities. However, the high-resolution comparison of particular phenomena in human life with specific paleoecological events is restricted by numerous factors. First of all, different speed and sequence of natural changes and human response to them (from quick decisions to gradual adaptation to new conditions), availability and accuracy of absolute dating, and finally, just the variety and quality of the information base.

The climatic event of ca. 8200 BP, known as 8.2 ka Cold Event, is considered as a relatively short-term global cooling of the Middle Holocene in the context of generally increasing annual temperatures and humidity (up to the climatic maximum). Its influence on the historical process is widely evidenced as a prolonged period of drought and cooling in the Eastern Mediterranean, North and East Africa, which was encountered by the early Neolithic cultures (Weninger et al. 2006). In the forest zone of Eastern Europe, this event coincided with the final stage of the Mesolithic, i.e. societies of hunter-fishers and gatherers. Around that time, the first pottery began to penetrate the region, which prompted researchers to the idea of migration of the southern Neolithic population to the north along large river routes (for example, Spiridonova, Aleshinskaya 1999; Aleshinskaya et al. 2001; Mazurkevich et al. 2013, p. 99-100, etc.). However, other components of the Neolithic way of life (first of all, agriculture and cattle farming as the basis of the economy) were not adopted by the local population, which kept forager forms of economy for a few millennia more. Inhabitants of the forest zone chose strategically advantageous sites on shores of large lakes and rivers, often with swampy surroundings, which created a relatively stable complex system of aquatic and terrestrial food resources.

Changes in the economy and material culture on the eve of pottery production expansion among forager societies in the forest zone of Eastern Europe and in particular the Upper Volga basin have repeatedly been under detailed consideration (Kostyleva 2003; Lozovski 2001; 2003; Lozovski, Mazurkevich 2014, etc.), although the mechanism and reasons for this epochal phenomenon have not been revealed. We can only state that the preconditions were formed at the end of the $7^{\text {th }}$ - the beginning of the

Olga Lozovskaya, PhD, Head of Laboratory for Experimental Traceology, Institute for the History of Material Culture of Russian Academy of Sciences, Dvortsovaya naberezhnaya, 18, St. Petersburg, 191186, Russia; olozamostje@gmail.com ORCID: 0000-0001-5536-0773

Ekaterina Ershova, PhD, Associate Professor, Department of Ecology and Plant Geography, Faculty of Biology, Lomonosov Moscow State University, Leninskie Gory, 1/12, Moscow, 119234, Russia; Senior Research Fellow, Interdisciplinary Innovative and Scientific-Practical Archaeological and Ethnological Research, Institute of International Relations, Kazan Federal University, Pushkina 1/55, Kazan, 420008, Russia; ekaterina.g.ershova@gmail.com

ORCID: 0000-0002-5421-9572 
$6^{\text {th }}$ mil. cal BC, which coincides with the $8.2 \mathrm{ka}$ Cold Event and its implications. Let us consider what this sharp cooling was manifested in at the local level on the basis of specific examples.

\subsection{KA COLD EVENT. KEY FACTS}

The 8.2 ka cold episode has been thoroughly studied and reconstructed for many regions of Europe based on isotopic data from ice and cave cores, as well as from independent series of paleobiological data. It is believed that the reason for the strong but short-term cooling was the change in the circulation regime of the ocean and atmosphere after the collapse of the last ice sheet. The most dramatic cooling is reconstructed for the North Atlantic, where the decrease in average annual temperatures exceeded $3^{\circ} \mathrm{C}$. In Central Europe and Baltic, the cooling was somewhat weaker $\left(1-2^{\circ} \mathrm{C}\right)$. Duration of the cold episode in different areas and based on various data is estimated at 150-300 years (Borzenkova et al. 2017). The impact of the 8.2 ka Event on the vegetation cover is reflected in the pollen diagrams. In Western Europe and Baltics, the cooling was expressed in reduction or even complete disappearance of thermophilic wood species (oak, elm, linden, hazel) in the pollen spectrum and a simultaneous increase in the amount of birch pollen. Many pollen diagrams of the European territory of Russia also show a "late boreal cooling" (Khotinsky et al. 1991), however, it is less pronounced than in Northern Europe, which gives grounds for conclusions about a milder manifestation of the 8.2 ka Event (Borzenkova et al. 2017). Nevertheless, in several pollen diagrams with a high degree of temporal resolution one can see short-term changes in the spectra similar to those described for Northern Europe and the Baltics. For the Moscow region, two relatively well-dated and sufficiently detailed pollen diagrams covering the entire Holocene have been published to date: these are the sediment core sample of Lake Dolgoe (Kremenetski et al. 2000; Borisova 2018) and the peat bog in the Losiny Ostrov (i.e. Elk Island) National Park (Myagkaya, Ershova 2020) (Fig. 1a). The both columns reflect a regional signal and can act as a basis for reconstructing changes in vegetation and climate in the Volga-Oka interfluve. The 8.2 ka Climatic Event is quite distinctly revealed in the both diagrams in the form of a noticeable but short-term reduction in pollen of broadleaved trees, especially oak, and a peak of birch pollen. In the Elk Island, there is also a sharp change in the botanical composition of peat, which indicates a relatively short-term increase of the hydration level.

\section{ARCHAEOLOGICAL MATERIALS}

Vegetation is most sensitive to climate change. In most cases, at sites of the Stone Age and even later periods, wood and other plant remains have not been preserved. Wetland lake settlements of the Mesolithic - Bronze Age represent a rare type of sites where fragile organic materials are represented in a more or less complete spectrum. This provides for a unique opportunity to compare different data in order to reconstruct a more complete picture of the vegetation change.

Several Late Mesolithic sites with archaeological layers dating back to the end of the $7^{\text {th }}$ mil. cal BC are known in the Volga-Oka region. Site Zamostje 2 is the most informative among them (Fig. 1a).

The site has been investigated since 1989 (V.M. Lozovski, O.V. Lozovskaya), $164 \mathrm{~m}^{2}$ are excavated up to date (Fig. 1e). Three of the five archaeological layers date from the period of our interest: two date from the Late and Final Mesolithic in the 6300-5750 cal BC interval. A layer with ceramics of the Upper Volga culture directly overlaps them (ca. 5700-5300 cal BC). Numerous artefacts of stone, flint, bone, antler, as well as wood and plant fibers were found in all the three layers. Selective determinations of wood by (the method of) identifying structural features of cells were carried out by Maria I. Kolosova (The State Hermitage Museum, St. Petersburg) in 2009-2013 (Lozovskaya, Kolosova 2011; Ershova, Lozovskaya 2018). The species composition of charcoal (samples from sieving) was determined by Alexandre A. Alexandrovskiy (Institute of Geography of RAS, Moscow) in 2015-2017 (Alexandrovskiy 2018). Analysis of macrobotanical residues was carried out by Eleonora A. Krutous (Institute of Geochemistry and Geophysics AS of Belarus, Minsk) in 1991 (seeds) (Krutous 2018), Marian Berihuete-Azorín (Institute of Botany, University of Hohenheim) (seeds) in 2013-2018 (Berihuete, Lozovskaya 2014; Berihuete 2018) and Ludmila I. Abramova (Moscow State University) (peat) in 2011-2013 (Ershova 2013). Palynological analysis and reconstruction of vegetation were carried out by Elena $A$. Spiridonova (Institute of Archeology of RAS) in 1989-1997 (Aleshinskaya et al. 2001) and Ekaterina G. Ershova (Moscow State University) in 2013-2018 (Ershova 2013; Ershova, Lozovskaya 2018). Radiocarbon dates for the period under consideration were obtained in laboratories of the Geological Institute of RAS, Institute for the History of Material Culture of RAS, Russian State Pedagogical University, the Universities of Kiel and Uppsala, and the Centro Nacional de 
Aceleradores in Sevilla in 1989-2018 (Lozovski et al. 2014; Lozovskaya, Lozovski 2018).

Inhabitants of the site lived off intensive fishing and hunting for elk and beaver, as well as water and wetland birds. The archaeological inventory includes evidence of all activities typical for a base settlement. In the Late Mesolithic layer, some data indicates a year-round habitation (Lozovskaya, Lozovski 2018).

\section{METHOD}

Pollen analysis. We used the data of sporepollen analysis from several sections studied at different time during excavations of the site Zamostje 2. Two main stratigraphic sections are sq. A9-A12 (1995-2000) and sq. AA18 (2013) (Fig. 2); the data on sections near the fish-traps (sq. A8' and 2, 2013) was also partially used (Fig. 1e). For more clarity, the analysis results were recalculated using the same method - the participation of pollen taxa was calculated in \% of the total pollen, and the participation of spore ones - in \% of the total of pollen and spores. Some taxa were combined into groups: broadleaf forest trees, including Corylus, terrestrial grasses, aquatic plants, ferns.

Dating. For section AA18 (2013), based on seven radiocarbon dates in the OxCal program (Reimer et al. 2020), a model of the sediment accumulation rate was constructed (Fig. 4), and using this model, dates were calculated for all samples, starting from the lower layer of the Late Mesolithic (LM LL). The beginning of peaty deposits accumulation was determined from a series of 14C dates obtained from the underlying sapropel (peaty gyttja) in several sections. Since all dates are close enough to each other, we combined them in the OxCal program. We assume the obtained result to be the lower boundary) of the beginning of archaeological layer accumulation.

Comparison. For comparison, we used the published data of pollen analysis for the two objects located closest to the Zamostje 2 site (Fig. 1a): a column of lacustrine sediments from the Lake Dolgoe (Kremenetskiy et al. 2000; Borisova 2018) and a peat column from a swamp in the center of the Losiny Ostrov National Park (Myagkaya, Ershova 2020).

\section{RESULTS}

The considered period of time, from the viewpoint of impact assessment of the 8200 cal BP cooling on the landscape surrounding the lake settlement at Zamostje 2, is reflected in the sediments of the Late Mesolithic Upper (LM UL) and Final Mesolithic (FM) archaeological layers. In the most complete section A9-A12, layers included two horizons each (Fig. 2).
The lower horizon of the LM Upper layer is a dark gray sapropel (gyttja) with poorly decomposed plant remains; numerous fragments of wood chips were evenly and densely distributed; many branches and other large wood fragments were found; remains of fish bones and broken scales are abundant.

The upper horizon of the LM Upper layer is represented by deposits of dark gray sapropel, sometimes black, sandy, with numerous macroremains such as small wood chips and bark, fish scales and bones, as well as small charcoals. The density of finds and saturation with sandy inclusions is especially high in the upper part of the layer. It is difficult to say for sure whether this is related to the residential surface or also to the washing out of the sediment as a result of natural water processes. Yu.A. Lavrushin (Aleshinskaya 2001, p. 250) unambiguously indicated the intact state of the layer, estimating the duration of sedimentation at several decades. The upper boundary of the layer is clearly delineated (with the exception of pit AA18).

It is overlapped by a $5-10 \mathrm{~cm}$ thick horizon of olive sapropel with plant remains (leaves, roots, etc.) and numerous fragments of small branches and bark. The upper horizon of the FM layer is represented by dark gray sandy sapropel, with fine grit, abundant wood chips, big charcoals, plant seeds, and small fish bones. The layer has a limited distribution - so it is absent near the fish-traps, while the surface of the LM UL shows numerous traces of erosion. In pit AA18, which is characterized by a more regular and even accumulation of artefacts, the FM layer is homogeneous: it is a dark gray sapropel with numerous plant and small woody remains as bark and wooden crumbs, as well as many broken fish scales. In section A9-A12, the layer was interpreted as a kind of a mud flow, which incorporated some archaeological remains (Aleshinskaya et al. 2001, p. 250). It contained pieces of twisted ropes made of willow fibers (identified by M.I. Kolosova) (Lozovskaya, Lozovski 2018, Fig. 67).

For these two archaeological layers, there are the following $14 \mathrm{C}$ dates made on sapropel, wood and charcoal (Tables 1 and 2).

Thus, it is obvious that during the formation of the FM layer, i.e., ca. 5900-5750 cal BC (seven $14 \mathrm{C}$ dates), sedimentation proceeded differently in various parts of the site; the investigated zone covers $35 \mathrm{~m}$ along the modern channel of the Dubna River (Fig. 1e). The data available today on the relief reconstruction of the site indicates existence of a paleo water reservoir on the eastern side (slope and fishing structures in the SE part), a temporary channel at the trench with fish-traps 
Table 1. Zamostje 2. Calibrated 14C dates for Late Mesolithic Upper layer and Final Mesolithic layer for: a sapropel (peaty gyttja); b - wood (fish constructions, piles from fish-fences, branches and chips from archaeological layers); c - charcoal

(2)

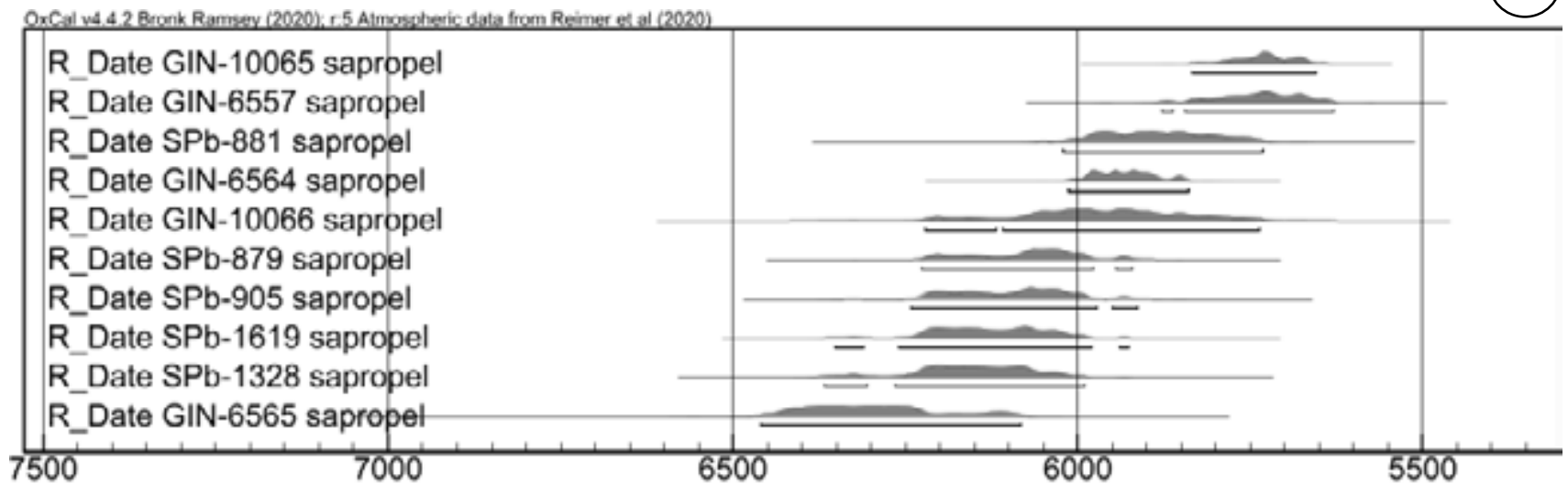

Calibrated date (calBC)

(b)

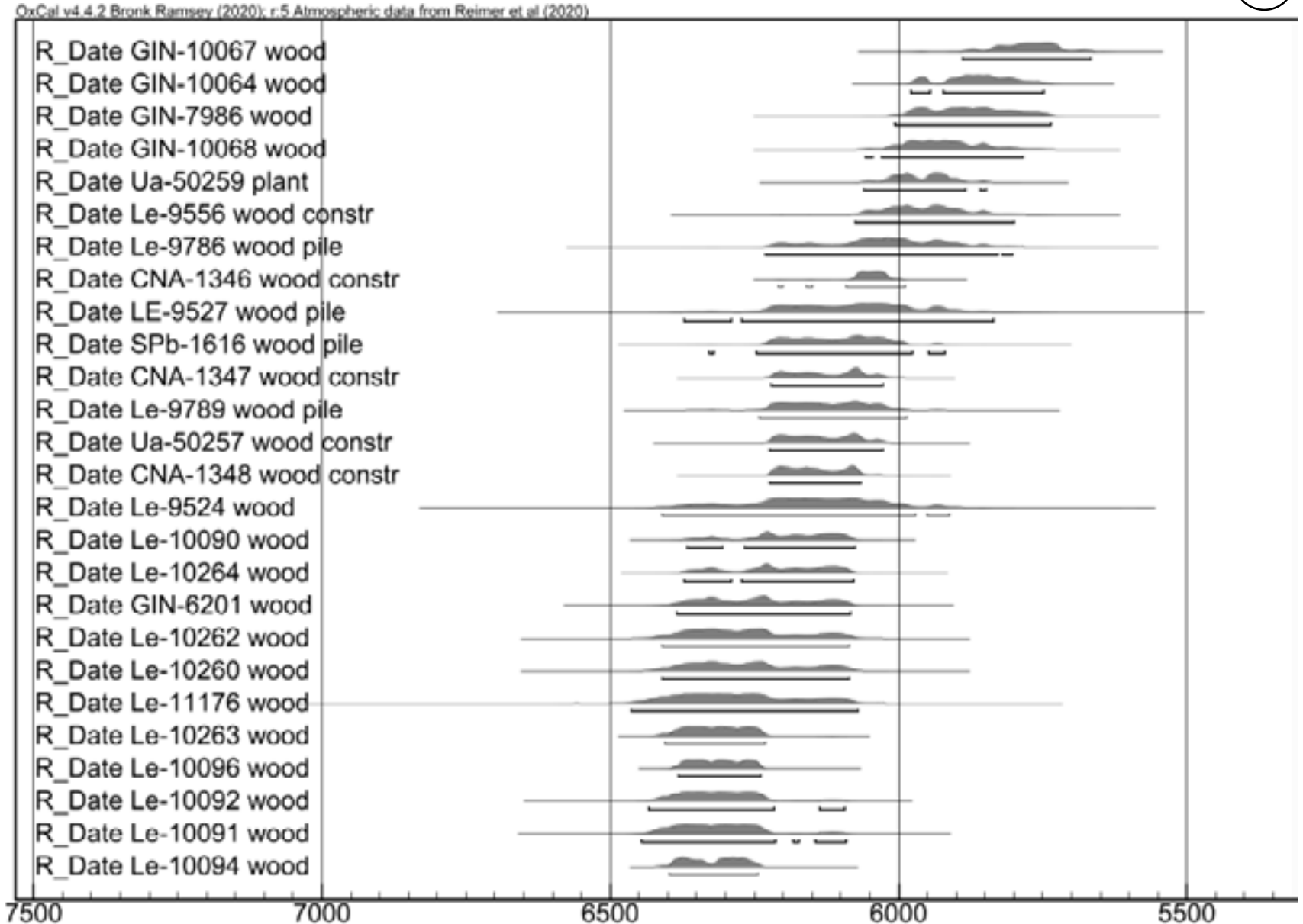

Calibrated date (calBC)

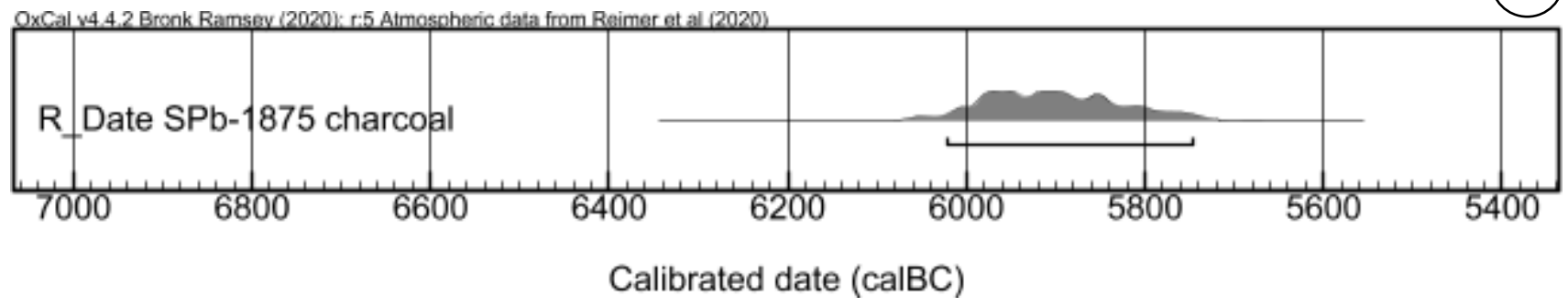


Table 2. Zamostje 2. Radiocarbon dates for Late Mesolithic Upper layer and Final Mesolithic layer

\begin{tabular}{|c|c|c|c|c|}
\hline Lab. No & BP & cal BC & material & sample context \\
\hline \multicolumn{5}{|c|}{ Final Mesolithic layer } \\
\hline GIN-10065 & $6850 \pm 40$ & $-5837-5659$ & sapropel & 1996, layer 5, sq. A11 \\
\hline GIN-6557 & $6850 \pm 60$ & $-5873-5635$ & sapropel & 1990, layer 5, sq. 2 \\
\hline GIN-10067 & $6890 \pm 50$ & $-5886-5674$ & wood & 1996, layer 5, sq. A11 \\
\hline GIN-10064 & $6980 \pm 40$ & $-5981-5753$ & wood & 1996, layer 6, sq. A10 \\
\hline GIN-7986 & $7000 \pm 70$ & $-6003-5741$ & wood worked & 1991, layer 5, sq. Г15 \\
\hline SPb-881 & $7010 \pm 80$ & $-6021-5733$ & sapropel & 2013, western section, sq. AA18, $-380-372$, layer $5 / 6$ \\
\hline SPb-1875 & $7030 \pm 70$ & $-6022-5752$ & charcoal & 1996, layer 5, sieving \\
\hline \multicolumn{5}{|c|}{ Late Mesolithic, Upper layer } \\
\hline GIN-6564 & $7050 \pm 40$ & $-6009-5846$ & sapropel & 1990, layer 6, sq. A5 \\
\hline GIN-10068 & $7050 \pm 60$ & $-6033-5789$ & wood & 1996, layer 7, sq. 612 \\
\hline Ua-50259 & $7087 \pm 45$ & $-6052-5885$ & plant fiber & 2011, layer 5a, sq. A8' , sieving, net knot 13 \\
\hline Le-9556 & $7090 \pm 70$ & $-6081-5796$ & wood & 2011, SubA, fish-screen №1, pine, sq. K XIII-XVI \\
\hline KIA-51096 & $7094 \pm 38$ & $-6047-5896$ & human bone & 1996, layer 7, sq. B9 \\
\hline GIN-10066 & $7100 \pm 120$ & $-6217-5743$ & sapropel & 1996, layer 7 , sq. 612 \\
\hline Le-9786 & $7150 \pm 100$ & $-6232-5811$ & wood & 2011, SubA, vert. pile № 117, sq. MH XIV, bird cherry \\
\hline CNA-1346 & $7198 \pm 30$ & $-6202-6002$ & wood & 2011, SubA, fish-screen №1, pine, sq. K XIII-XVI \\
\hline Le-9527 & $7200 \pm 120$ & $-6363-5843$ & wood & 2011, SubA, vert. pile № 120/127, sq. ЛXV, hornbeam \\
\hline SPb-879 & $7200 \pm 70$ & $-6226-5927$ & sapropel & 2013, western section, sq. AA18, $-390-380$, layer 7 \\
\hline GIN-7988 & $7200 \pm 90$ & $-6247-5892$ & elk bone & 1991, layer 6, sq. Г15, Д16 \\
\hline SPb-905 & $7220 \pm 80$ & $-6245-5920$ & sapropel & 2013, western section, sq. A8',$-354-364$ \\
\hline SPb-1616 & $7232 \pm 80$ & $-6252-5979$ & wood & 2012, SubA, vert. pile № 134, sq. K VII, alder \\
\hline CNA-1347 & $7248 \pm 35$ & $-6216-6035$ & wood & 2011, SubA, fish-screen №4, sq. И XVII, pine \\
\hline Le-9789 & $7250 \pm 70$ & $-6243-5996$ & wood & 2012, SubA, vert. pile № 134, sq. K VII, alder \\
\hline SPb-1619 & $7253 \pm 80$ & $-6346-5985$ & sapropel & 2013, western section, sq. A8' , -364-374 \\
\hline Ua-50257 & $7257 \pm 45$ & $-6223-6034$ & wood & 2014, SubA, fish-screen № 2, sq. M XVIII \\
\hline CNA-1348 & $7267 \pm 31$ & $-6217-6064$ & wood & 2011, SubA, fish-screen № 2, sq. КЛ XVII, willow \\
\hline Le-9524 & $7270 \pm 120$ & $-6406-5916$ & wood & 2011, layer 6a, sq. Б8 '-A10', №155, -399-411 \\
\hline SPb-1328 & $7280 \pm 80$ & $-6356-6005$ & sapropel & 2013, western section, sq. AA18, $-400-390$, layer 7 \\
\hline Le-10090 & $7350 \pm 45$ & $-6361-6079$ & wood & 2013, layer 8, sq. AA18-19, sieving \\
\hline Le-10264 & $7360 \pm 50$ & $-6369-6088$ & wood & 2013, layer 6a, sq. E8'/3, -411-418 \\
\hline GIN-6201 & $7380 \pm 60$ & $-6392-6094$ & wood & 1989, layer 7, sq. \\
\hline Le-10262 & $7400+75$ & $-6420-6095$ & wood & 2013, layer 7, sq. 7, № 111/112, -463-476 \\
\hline Le-10260 & $7400 \pm 75$ & $-6420-6095$ & wood & 2013, layer 7, sq. AA18-19 \\
\hline Le-11176 & $7430 \pm 110$ & $-6467-6067$ & wood & 2013, sq. 14, vert. pile № 165/244 \\
\hline Le-10263 & $7440+40$ & $-6403-6232$ & wood & 2013, layer 8a, sq. A9 '59 '10', № 214-216, -428-450 \\
\hline Le-10096 & $7440 \pm 20$ & $-6381-6245$ & wood & 2013, layer 8, sq. 4 \\
\hline GIN-6565 & $7450 \pm 100$ & $-6467-6088$ & sapropel & 1990, layer 7, sq. A5 \\
\hline Le-10091 & $7450 \pm 70$ & $-6453-6117$ & wood & 2013, layer 8, sq. AA18-19, sieving \\
\hline Le-10094 & $7460 \pm 20$ & $-6399-6251$ & wood & 2013, layer 5a, sq. 59' \\
\hline
\end{tabular}

Dates have been calibrating using O[Cal v 4.2.4 Bronk Ramsay (2009)\$ $\wedge^{\wedge} 5$ IntCal13 atmospheric curve (Reimer et al., 2013) 
(1989 / 2010-13), a deeply prominent cape in the central part and a small backwater with calm sedimentation from the northern side (Fig. 1b). The age of the stream with fish-traps is estimated as no younger than $6052-5885 \mathrm{cal}$ BC based on the $14 \mathrm{C}$ date obtained for the fish net knot (from sieving) 7087 $\pm 45 \mathrm{BP}$ (Ua-50259) (Table 2).

However, evidence of settlement activities for the LM UL (during more or less long visits, we are not talking about continuous habitation) is recorded for about four centuries 6300$5900 \mathrm{cal} \mathrm{BC}$, and a series of dates falls within ca. 6200-6050 cal BC. Most notably, the wooden fishing structures of the LM UL (fish-screens made of pine splinters at the bottom of the Dubna channel) and several piles of fish-fences (Fig. 1c) are definitely dated to this interval.

In the FM layer, on the contrary, not a single wooden structure or vertical pile has been found yet, taking into account the currently available 58 radiocarbon dates for underwater objects (Lozovski et al. 2013: 74-75; Lozovskaya et al. 2016). It should be noted that the age of all these objects (except for the fish-traps in the Early Neolithic layer in the surface excavation) is determined by direct $14 \mathrm{C}$ dating. This phenomenon can be explained, for example, by a temporary movement of the fishing area to some neighboring area.

\section{VEGETATION CHANGES ACCORDING TO POLLEN ANALYSIS DATA OF ZAMOSTJE 2}

In the context of a rather slow and progressive development of the forest and vegetation cover, which we observe in the pollen columns of Zamostje 2 for more than a millennium, at least from the middle of the Boreal, even small changes that took place at the end of the $7^{\text {th }}$ mil. cal BC are gaining in importance.

Since the pollen diagrams of the two sections shown in Fig. 3 reflect similar dynamics, development of the vegetation cover in the vicinity of the site can be described by the both columns as follows.

Four radiocarbon dates from the clayey sapropel underlying the archaeological layers give us an idea of when the deposits accumulation began; the result of combining dates in $\mathrm{Ox}-$ Cal shows the period between $8792 \pm 211$ and $8581 \pm 179$ cal BP. Starting with this period and up to 8200 cal BP, i.e. during the accumulation of LM LL and partially LM UL, birch dominates in the pollen spectra $(35-55 \%$ of the total spectrum), pine makes about $20 \%$, which is a relatively small figure, taking into account its high pollen productivity and volatility, spruce pollen is present, but singularly, perhaps, it was brought from neighboring regions. From the very beginning of the period, broad-leaved forest species (elm, linden, oak, hazel) and black alder (about $5 \%$ ) are present in significant quantities (about $10 \%$ in total). Grass pollen makes a rather large share - about $10 \%$ - in the test-pit of 2013 and up to $20 \%$ in the trench of 1996 . It can be assumed that, although birch forests were most common in the vicinity of Zamostje 2 during the Lower and Upper layers of the Late Mesolithic, there were also areas of elm forests, communities with the participation of oak, linden, and hazel in the undergrowth, as well as open spaces occupied by wet meadows and reed marshes. Similar data were obtained for other sections of the site (sq. A8' and 2).

This data is well harmonized with the regional data: in the diagrams of the Lake Dolgoe and Losiny Ostrov (Borisova 2018; Myagkaya, Ershova 2020), the respective period is also characterized by a pollen spectra dominated by birch with a small amount of pine and broadleaved species. At the same time, the beginning of broadleaf forests distribution across the whole region, according to the simulated dates, refers to the period of 9100 (Dolgoe Lake) -8800 cal BP (Losiny Ostrov). By the time the Mesolithic hunter-fishers had settled in the region, broadleaf forests had already begun to form, although significant areas of birch forests and open treeless grass communities were still in place. Such communities - meadows and marshes - were apparently widespread along the banks of water bodies in a vast lake basin near Zamostje 2 .

In the period of 8500-8200 cal BP, diagrams of Zamostje 2 show the maximum participation of birch (up to $50 \%$ of the total spectrum). It is well synchronized with the regional pollen diagrams. Both in the column from the Lake Dolgoe and in Losiny Ostrov during the same period, there is a peak of birch (up to $70 \%$ of the total spectrum) and a noticeable reduction in broadleaved species, especially oak. A similar dynamics was described for many pollen columns of Western Europe and the Baltic States (Borzenkova et al. 2017), which is usually interpreted as a response of vegetation to $8.2 \mathrm{ka} \mathrm{CE}$, expressed in the degradation of forests already formed by that time from thermophilic broad-leaved species and their replacement with less demanding warm birch forests. In the diagram of AA18 section of 2013 from Zamostje 2 (Fig. 3), at the level of the modeled date 8200 cal BP, one can also see a drop in the curves of broadleaf species and, especially, alder, but it looks weaker and more short-timed than on the regional diagrams. We can cautiously assume that the features of the 
lowland landscape and the milder microclimate smoothed out the effect of sharp fluctuations in temperature and humidity on local vegetation.

After 8200 cal BP, the pollen spectra of Zamostje 2 abruptly change: the participation of birch decreases, the participation of black alder sharply increases, the participation of oak, elm, linden and hazel is restored, and a hornbeam appears sporadically. In the both trenches, pine growth is also noted (up to $30-50 \%$ of the total spectrum). The share of meadow grasses decreases, while the share of spore (mainly forest ferns) increases. A similar trend is observed in the both regional charts. Thus, all available pollen data indicates significant transformations of the vegetation cover throughout the region in the short period immediately following the 8200 cal BP event and are apparently associated with both a sharp warming and a change in the water level. The composition of forest communities and their area also changed. In general, throughout the region, light birch forests were largely replaced by broadleaf forests, meadows in river and lake valleys are overgrown with alder. The latest process - an increase in the area of alder forests due to the reduction of meadow vegetation is especially clearly reflected in the diagrams of Zamostje 2 .

The dynamics of pine during this period is of a particular interest. In the regional diagrams, after a minimum, practically, an absence of pine in the period $8500-8000 \mathrm{cal} \mathrm{BP}$, its growth is observed (up to $30 \%$ of the total spectrum), after which its participation again drops to a minimum. This extended in time and weakly expressed pine peak dates from 8000-7300 cal BP in the both diagrams. In the sections of the Zamostje 2 site, the same pine peak is much more pronounced (up to $50 \%$ of the pollen spectrum), but its dates in the two pits are not the same: in the AA18 section of 2013 it is dated $7900-7300$ cal BP, which coincides with the regional data, and in the excavation of 1996, according to the available radiocarbon dates, it corresponds to a shorter period, approximately 8000-7800 cal BP (?).

We can only speculate on the underlying reason for a rather long - up to several hundred years - increase in the share of pine in the region. This may be a long-term delayed response to the $8.2 \mathrm{ka}$ CE event (restoration through pine in place of previously degraded broadleaf forests). Perhaps this is not related to 8.2 ka CE but to an independent climatic event or several events associated with fires in the period of 8000$7300 \mathrm{cal}$ BP. There is evidence of large fires in the Moscow region dated to this period (Alexandrovskiy et al. 2018). This is partly confirmed in Zamostje 2, given the highest saturation of the
Final Mesolithic layer with charcoal (for which there is a date of $7030 \pm 70 \mathrm{BP}$ ). Sharp and shortterm pine peaks belonging to the same period can be observed in other local diagrams in the Moskva River valley (Ershova et al. 2013). Based on the currently available data, we can state that the increase in the share of pine in several areas of the Moscow region during that period was more likely associated with local events (fires) than with general regional trends.

After 7400 cal BP in the 2013 section and after 7800 cal BP in the 1996 section, there is a decrease in the proportion of pine, a sharp increase in alder, and a moderate increase in broadleaved species. The share of grasses increases again, mainly due to gramineous plants, and the total number of meadow taxa also increases. The spectra reflect general dynamics of the region the maximum distribution of deciduous forests in conditions of a climatic optimum. However, the spectra of Zamostje 2 also have noticeable differences from the regional spectra of the same period: they contain less birch and broad-leaved trees, more alder, pine, and meadow grasses. We can assume that it reflects formation of a specific complex of plant communities in a vast ancient lake basin, consisting of swampy black alder forests, flooded meadows, and lowland marshes in combination with areas of deciduous forests and pine forests at higher levels.

An important general characteristic of changes in this period is related to a pronounced lowering of groundwater, which is confirmed, on the one hand, by the behavior of archaeological layers and their filling, and on the other hand, by an increase in the number of terrestrial taxa in the spore-pollen spectra.

\section{ANTHRACOLOGICAL ANALYSIS AND ANAL- YSIS OF WOODEN INVENTORY REMAINS}

An additional source of changes in the forests around the site can be provided by data on the species composition of charcoal (Aleksandrovsky 2018). However, it should be noted that the results have some limitations due to the irregularity of sampling (sieving from random squares), the lack of a reliable connection with the hearth structures and deliberate choice when it comes to the anthropogenic origin of charcoal in the layer. One sample from the FM layer gave a $14 \mathrm{C}$ age of $7030 \pm 70 \mathrm{BP}(\mathrm{SPb}-1875)$ / 60225752 cal BC. As for the quantity, the sample is quite representative: 683 charcoals were analyzed for two horizons of the LM UL (separately) and one horizon of the FM layer.

An almost complete absence of pine turned out to be a sensation: together with undifferentiated conifers, its number was 2 (LM UL, low hori- 
zon), 9 (LM UL, upper horizon) and 11 (FM) specimens $(1.8,2.8$, and $4.2 \%$, respectively). Elm and birch were the most numerous, with the proportion of elm growing from 15-18\% in the FM layer to $30 \%$, and the highest percentage of birch was noted, on the contrary, in the lower horizon of the LM UL - $24 \%$ plus $33 \%$ of diffuse-porous undivided; in the FM layer, these index are 12 and $23 \%$, respectively. Maple, linden and - in the two upper layers - alder are also represented.

The presented regularities can hardly be explained only by problems with availability of various types of raw materials, since local population actively used pine at all stages of the site's existence. Its share in the inventory of the LM UL is especially noticeable (almost 50\%, Ershova, Lozovskaya 2018: p. 37, Table 1) (Fig. 5b): splitted pine and branches were used for various household items, small pickets, as well as long splinters for fishing structures (Fig. 1c) - characteristics of pine wood were best suited for this. At the same time, other tree species were used for stakes (fish-fences), in particular, alder and bird cherry - trees of a inner circle. Bird cherry berries are found in abundance in the layers of the Late Mesolithic (Berihuete, Lozovskaya 2014). Birch, willow, elm, ash, oak and spruce also served as raw materials for other products. Compared with the underlying LM LL, where pine occupied only one fifth $(22 \%)$ of the species composition of worked wood (Fig. 5a), almost on par with birch, elm (19\% each) and willow (18\%) (bird cherry, ash, alder, maple, spruce, viburnum are also represented - from 6 to $1 \%$ in descending order).

The wood inventory of the FM layer is not numerous; there are no structures or vertical piles in the water. There are few species determinations (only 8), but pine, willow, birch and elm are represented; without explicit priorities. Analysis of macroremains in pit AA18 (Berihuete 2018) indicates presence of many berries of bird cherry, raspberry, viburnum, and numerous seeds of goosefoot species. Unfortunately, the data for the Late Mesolithic layers is given in an accumulated form, so a detailed comparison is impossible. But it seems that their number increased remarkably further to the Neolithic.

So, analysis of the wood inventory indicates a possible increase in the role of pine wood in the Late Mesolithic Upper layer compared to the earlier layer. However, their optimal characteristics for splitting into splinters retained its relevance later (Early Neolithic fish-traps, for example).

Finally, according to Ludmila I. Abramova, in the sample of peat from the LM UL 20 (25) \% remains of coniferous wood were determined, no deciduous ones. In the sample from the FM layer, on the contrary, 25 (30) \% are represented by remains of deciduous, no conifers.

\section{CHANGES IN MATERIAL CULTURE}

According to various remains of the material culture in the both layers, even taking into account a "small number" of finds in the FM layer and their possibly displaced nature ("mud flows in humid conditions"), the population did not leave these places during the period of 8.2 Cold Event and its consequences.

At the same time, we see a number of cultural, typological and technological changes that can be associated with both internal development, including a response to climate / landscape change, and external impulses.

The Late Mesolithic complex of Zamostje 2 as a whole has many common features with the synchronous sites of the Volga-Oka interfluve, but its cultural interpretation remains open (for a discussion on this topic, see Lozovski 2014; Lozovski et al. 2009). And only with the appearance of the Upper Volga pottery in the Early Neolithic, a more or less unified cultural community was established in the area. Based on materials from the site, the first ceramics and the beginning of the Neolithic are dated to ca. 5700 cal BC (Meadows et al. 2015).

The most notable changes took place in the way to fishing. Locking fishing techniques appeared here in the last quarter of the $7^{\text {th }}$ mil. cal BC. Dates for the three constructions from pine splinters found at the bottom of the modern riverbed fit into the interval 6223-6002 cal BC. The same range overlaps also two of the dated fish-fence piles (Nos120 / 127 and 134) (Fig. 1c; Tables 1b and 2) (Lozovski et al. 2013).

In the Final Mesolithic, there is no data on fishing structures. In the Early Neolithic, a different type of equipment appears - fish-traps surrounded by barrage structures made of piles, sticks, branches, and possibly nets (Fig. 1d). But their age is estimated ca. 5615-5383 cal BC (Lozovski et al. 2013).

The typology of fishhooks is quite indicative as well: thin miniature hooks with an even shaft and a rounded lower edge and a short appressed curved tooth are distinguished in the LM UL (Fig. 6: 26-30). In the FM layers, for a short period, there appear items with a thickened shaft and a short sharp point separated by a slit (Fig. 6: 14-16). The third technical-typological solution is noted in the Early Neolithic, where the production of the identical fishhooks - with help of double-sided grooves and a hole drilled at the intersection (Fig. 6:1-6) - can be considered as a culture-defining feature (fossile directeur) for the Upper Volga culture. 
Finally, a peculiar type of flat willow-leaved fishing gear with a hole for tying a line turned out to be common for the both Mesolithic layers (LM UL and FM) (Fig. 6: 12-13, 22-24). Considering that the catch composition, from the middle of the $7^{\text {th }}$ mil. cal $B C$, remained practically unchanged (Radu, Berset 2013), noticeable changes in the fishing gear and fishing structures could hardly have been a result of gradual adaptation but rather of external cultural implications.

The situation with hunting weapons is equally ambiguous. While the LM UL is characterized by the largest typological variety of arrowheads and barbed points, including slotted arrowheads with sharp barbs, for example, or short needleshaped points (Lozovskaya, Lozovski 2019), which are more characteristic for the upper horizon of the layer (i.e., synchronous with cooling). In the context of general continuity, all the three layers possess their distinctive types, e.g., in the Early Neolithic with a series of figured arrowheads with three thickenings and uni-lateral small-barbed points (Fig. 6: 7-9, 11).

Appearance at the very end of the Mesolithic of a very specific type of a sickle-shaped slotted tool with an original ornamentation as a relief zigzag in a deepened groove - neither the ornament nor the type of tool had any close items either before or after (Lozovskaya 2020) - seems to indicate the emergence of some new groups.

\section{CONCLUSIONS}

Analysis of archaeological and paleobotanical data associated with changes in vegetation cover and the response to them of human collectives during the second half of the $7^{\text {th }}$ - early $6^{\text {th }}$ mil. cal $\mathrm{BC}$ as a whole quite convincingly showed the general picture of an unstable ecological situation and discontinuity in development of material culture traditions.

While general tendencies of changes in the forests composition and the ratio of vegetation species in the vicinity of Zamostje 2 are similar to the regional trends traced in the diagrams of the Lake Dolgoe and Losiny Ostrov, in many cases we can observe smoother fluctuations in temperature and humidity for local vegetation under conditions of a milder microclimate of lowland landscapes. In addition, we cannot ignore that the behavior of forest communities could have been influenced not only by global climatic events, such as the 8.2 ka Cold Event, but also by more local independent phenomena such as forest fires.

The data of spore-pollen analysis is in concordance with the analysis of charcoals: the both methods show dominance of birch and a wide distribution of broad-leaved species in the Late Mesolithic layers, i.e., in the period up to $8.2 \mathrm{ka}$ CE. According to the data of anthracological analysis, the participation of oak, linden, and, especially, elm in the pollen spectra of the Upper Mesolithic layer is significantly underestimated in comparison with their real representation in the vegetation cover. Charcoal analysis also shows a low proportion of pine and its gradual growth from the Upper Mesolithic to the Final Mesolithic. Appearance of alder charcoals in the FM layer coincides with a sharp increase in the alder pollen curve in the same layer.

Analysis of wooden artefacts reveals a slightly different picture. Obviously, the choice of wood species was determined not only by availability of materials, but also by their specific properties. First of all, we are talking about large-scale use of pine for splitting into splinters and production of fishing structures (fish-traps, fish-screens). At the same time, the general dynamics of wood use, as well as the data of carpology, generally confirm the conclusions of palynology and anthracology.

Finally, with an undoubted general continuity of the economic strategies and most of the bone and flint implements, the period under consideration is characterized by at least three cultural influences, which are most clearly visible in the partial change of hunting and fishing equipment. At the same time, the earliest appearance of ceramics at the site ca. $5700 \mathrm{cal} \mathrm{BC}$ is synchronized, according to some data, with the peak of pine, which possibly occurred after large fires at the beginning of the $6^{\text {th }}$ mil. cal BC. However, this version needs to be additionally studied. Moreover, in the context of the obtained data, our interest has been drawn to earlier archaeological horizons and the question if the population of the site during 8.2 ka Cold Event was local in this area.

\section{ACKNOWLEDGEMENTS}

This work was supported by Program of FSR RAS No 0184-2019-0008; Moscow State University project No 14-1-21; Projects of RFBR Nos 11-06-00090a, 13-06-10007 k. 


\section{REFERENCES}

Aleshinskaya, A.S., Lavrushin, Yu.A., Spiridonova E.A. 2001. Geologo-paleoekologicheskiye sobytiya golotsena i sreda obitaniya drevnego cheloveka $v$ rayone arkheologicheskogo pamyatnika Zamostje 2. In: T. Manushina. V. Vishnevskiy. V. Lozovskiy. O. Lozovskaya (eds.) Kamennyi vek evropeyskikh ravnin: objekty iz organicheskikh materialov i struktura poseleniy kak otrazheniye chelovecheskoy kultury. Materialy mezhdunarodnoy konferentsii 1-5 july 1997. Sergiev Posad, 248-254. (in Russian)

Alexandrovskiy, A., Ershova, E., Ponomarenko, E., Krenke, N., Skripkin, V. 2018. Floodplain paleosols of Moskva river basin: Chronology and paleoenvironment. Radiocarbon, 60(4): 1169-1184.

Alexandrovskiy, A.L. 2018. The first results of the trees species determination on the charcoal from the Mesolithic layers. Zamostje 2 (Chapter 4). In: O. Lozovskaya, V. Lozovski (eds.) Site Zamostje 2 and landscape evolution in the Volga-Oka region during the Holocene. St. Petersbourg: IHMC RAS, 49-54. (in Russian) DOI: $10.31600 / 978-5-9909872-8-9-2018-49-53$

Berihuete Azorin, M., Lozovskaya, O.V. 2014. Evolution of plant use at the wetland site Zamostje 2, Sergiev Posad, Russia: First results. In: V. Lozovski, O. Lozovskaya (eds.) Prirodnaya sreda $i$ modeli adaptatsii ozernykh poseleniy v mezolite i neolite lesnoy zony Vostochnoy Evropy. St. Petersbourg: IHMC RAS, 74-79.

Berihuete, M. 2018. First results of the archaeobotanical study of the Test pit 2 Profile column (Chapter 3). In: O. Lozovskaya, V. Lozovski (eds.) Site Zamostje 2 and landscape evolution in the Volga-Oka region during the Holocene. St. Petersbourg: IHMC RAS, 41-49.

Borisova O.K. Vegetation development on the Upper Volga lowland and the adjacent uplands in the Holocene: reconstruction based on paleobotanical data (Chapter 1). In: O. Lozovskaya, V. Lozovski (eds.) Site Zamostje 2 and landscape evolution in the Volga-Oka region during the Holocene. St. Petersbourg: IHMC RAS, 2018. 9-30. (in Russian) DOI: 10.31600/978-5-9909872-8-9-2018-9-30

Borzenkova, I.I., Borisova, O.K., Zhiltsova, E.L., Sapelko, T.V. 2017. Kholodnyy epizod okolo 8200 let nazad v Severnoy Evrope: analiz empiricheskikh dannykh i vozmozhnykh prichin. Led i Sneg, 57 , № 1, 113-132. (in Russian).

Ershova E., 2013. Zamostje 2, 2013. Results of the botanical and pollen analysis. In: V. Lozovski, O. Lozovskaya, I. Clemente Conte (Eds.) Zamostje 2. Lake Settlement of the Mesolithic and Neolithic Fisherman in Upper Volga Region. St. Petersbourg: IHMC RAS, 182-193.

Ershova E., Lozovskaya, O. 2018. Paleoenvironment of Mesolithic and Neolithic settlements at Zamostje 2 according to botanical and pollen analysis. (Chapter 2). In: O. Lozovskaya, V. Lozovski (eds.) Site Zamostje 2 and landscape evolution in the Volga-Oka region during the Holocene. St. Petersbourg: IHMC RAS, 2018. 31-40. (in Russian) DOI: 10.31600/978-5-9909872-8-9-2018-31-40

Ershova, E. G., Berezina, N. A., Karina. E. V. 2013. Rastitelnost doliny Moskvy-reki v subborealnom periode (na rubezhe neolita i bronzovogo veka) po dannym sporovo-pyltsevogo analiza. Arkheologiya Podmoskovia, 9. Moscow: IA RAN, 257-267. (in Russian)

Khotinskiy, N.A.. Aleshinskaya, Z.V.. Guman, M.A.. Klimanov, V.A.. Cherkinskiy, A.E. 1991. Novaya skhema periodizatsii landshaftno-klimaticheskikh izmeneniy v golotsene. In: Izvestiya AN SSSR. Ser. geogr., 3, 30-42. (in Russian)

Kostyleva, E.L. 2003. Osnovnyye voprosy neolitizatsii tsentra Russkoy ravniny (osobennosti neolitizatsii lesnoy zony). In: V. Timofeev (ed.). Neolit - eneolit yuga i neolit severa Vostochnoy Evropy (novyye materialy. issledovaniya. problemy neolitizatsii regionov). St. Petersburg: IHMC RAS, 213-218. (in Russian)

Kremenetski, K.V., Borisova, O.K., Zelikson, E.M. 2000. The Late Glacial and Holocene history of vegetation in the Moscow region. Paleontological Journal, 34. Suppl. 1. S67-S74.

Krutous, E. 2018. Paleobotanical studies and paleogeographic reconstructions of site Zamostje 2 (Annex) In: O. Lozovskaya, V. Lozovski (eds.) Site Zamostje 2 and landscape evolution in the Volga-Oka region during the Holocene. St. Petersburg: IHMC RAS, 207-211. (in Russian)

Lozovskaya, O., Lozovski, V. 2018. Environment and subsistence conditions in Late Mesolithic and Neolithic at site Zamostje 2. (Chapter 7). In: O. Lozovskaya, V. Lozovski (eds.) Site Zamostje 2 and landscape evolution in the Volga-Oka region during the Holocene. St. Petersburg: IHMC RAS, 73-165. (in Russian) DOI: 10.31600/978-5-9909872-8-9-2018-73-165

Lozovskaya, O., Lozovski, V. 2019. Bone and Antler Projectile Points from Meso-Neolithic Site Zamostje 2, Moscow region, Russia. In: D. Groß, H. Lübke, J. Meadows, D. Jantzen (eds.) Working at the Sharp End: From Bone and Antler to Early Mesolithic Life in Northern Europe. Untersuchungen und Materialien zur Steinzeit in Schleswig-Holstein und im Ostseeraum. Band 10. Kiel/Hamburg: Wachholtz, 341-365. DOI: $10.23797 / 9783529018619-14$

Lozovskaya, O.V. 2020. Motiv zigzaga v kostyanom inventare stoyanki Zamostje 2 (pozdniy mezolit - ranniy neolit): tekhniki i kontekst. Kratkiye soobshcheniya Instituta arkheologii, 261. (in Russian)

Lozovskaya, O.V., Kolosova, M.I. 2011. Osobennosti ispolzovaniya syria dlya izgotovleniya derevyannogo inventarya v pozdnem mezolite po materialam stoyanki Zamostje 2. In: Trudy III (XIX) Vserossiyskogo arkheologicheskogo syezda. Velikiy Novgorod - Staraya Russa. T.1. St. Petersburg - Moscow-Velikiy Novgorod, 168-169. (in Russian)

Lozovskaya, O.V., Lozovski, V.M., Zaytseva, G.I., Kulkova, M.A., Sementsov, A.A., Meadows, J., Rishko, S.A. 2016. Neoliticheskiye drevnosti stoyanki Zamostje 2. Katalog radiouglerodnykh dat. In: G.I. Zaytseva, O.V. Lozovskaya, A.A. Vybornov, A.N. Mazurkevich (comp.). Radiouglerodnaya khronologiya epokhi neolita Vostochnoy Evropy VII-III tys. do n. e. Glava 12.1. Smolensk: Svitok, 182-202. (in Russian) 
Lozovski, V. M. 2001. Voprosy perekhoda ot mezolita k neolitu v Volgo-Okskom mezhdurechye (po materialam stoyanki Zamostje 2). In: T. Manushina. V. Vishnevskiy. V. Lozovskiy. O. Lozovskaya (eds.) Kamennyi vek evropeyskikh ravnin: objekty iz organicheskikh materialov i struktura poseleniy kak otrazheniye chelovecheskoy kultury. Materialy mezhdunarodnoy konferentsii 1-5 july 1997. Sergiev Posad, 265-272. (in Russian)

Lozovski, V. M. 2003. Perekhod ot lesnogo mezolita k lesnomu neolitu v Volgo-Okskom mezhdurechye (po materialam stoyankiZamostje2). In: V. Timofeev (ed.). Neolit-eneolityuga ineolitsevera Vostochnoy Evropy (novyye materialy. issledovaniya. problemy neolitizatsii regionov). St. Petersburg: IHMC RAS, 219-240. (in Russian)

Lozovski, V. M. 2013. Drevneyshaya keramika Vostochnoy Evropy. Kommentarii. Rossiyskiy arkheologicheskiy Ezhegodnik, 3.120-126. (in Russian)

Lozovski, V. M., Girya, E.Yu., Kravtsov, A.E. 2009. Mezolit Volgo-Okskogo mezhdurechia: tekhnologicheskiy podkhod. In: V.P. Chabay (ed.) Aktualnyye problemy pervobytnoy arkheologii Vostochnoy Evropy. Materialy konferentsii. posvyashchennoy 100-letiyu S.N. Bibikova. Arkheologicheskiy almanakh, 20. Donetsk: Donbass, 269-288. (in Russian)

Lozovski, V., Lozovskaya, O., Clemente-Conte, I., Mazurkevich, A., Gassiot-Ballbè, E. 2013. Wooden fishing structures on the Stone age site Zamostje 2. In: V. Lozovski, O. Lozovskaya, I. Clemente Conte (eds.) Zamostje 2. Lake Settlement of the Mesolithic and Neolithic Fisherman in Upper Volga Region. St. Petersbourg: IHMC RAS, 46-75.

Lozovski, V., Lozovskaya, O., Mazurkevich, A., Hookk, D., Kolosova, M. 2014. Late Mesolithic-Early Neolithic human adaptation to environmental changes at an ancient lake shore: The multi-layer Zamostje 2 site, Dubna River floodplain, Central Russia. In: M. Bronnikova and A. Panin (eds.). Human dimensions of palaeoenvironmental change: Geomorphic processes and geoarchaeology. Quaternary International, 324. 146-161.

Lozovski, V..M. 2014. Kremnevaya industriya mezoliticheskikh sloyev stoyanki Zamostje 2. In: Kamennyy vek: ot Atlantiki do Patsifiki. Zamyatninskiy sbornik, 3. St. Petersburg: MAE RAN, IHMC RAS, 244-292. (in Russian)

Lozovski, V.M., Mazurkevich, A.N. 2014. Nachalnyy etap neolita Evropeyskoy chasti Rossii po dannym analiza kamennykh industriy. In: Rossiyskiy arkheologicheskiy ezhegodnik, 4, 73-88. (in Russian)

Mazurkevich, A.N., Dolbunova, E.V., Kulkova, M.A. 2013. Keramicheskiye traditsii v rannem neolite Vostochnoy Evropy. In: In: Rossiyskiy arkheologicheskiy ezhegodnik, 3, 27-109. (in Russian)

Meadows, J., Lozovski, V., Lozovskaya, O., Lubke, H., Zaitceva, G.I., Kulkova, M.A. 2015. Place of Zamostje 2 site pottery assemblage within the overall chronology of Upper Volga-type pottery. In: V. Lozovski, O. Lozovskaya, A. Vybornov (eds). Neolithic cultures of Eastern Europe: chronology, paleoecology and cultural traditions. Materials of the international conference, dedicated to the $75^{\text {th }}$ Anniversary of Victor Tretyakov. St. Petersburg: IHMC RAS, 84-91. (in Russian)

Miagkaia, A., Ershova, E. 2020. A 10 000-year pollen and plant macrofossil record from the Losiny Ostrov national park (Moscow, Russia). In: IOP Conference Series: Earth and Environmental Science, 438(012018).

Radu, V., Desse-Berset, N. 2013. Fish and fishing at the site of Zamostje 2. In: V. Lozovski, O. Lozovskaya, I. Clemente Conte (eds.) Zamostje 2. Lake Settlement of the Mesolithic and Neolithic Fisherman in Upper Volga Region. St. Petersbourg: IHMC RAS, 194-213.

Reimer, P., Austin, W., Bard, E., Bayliss, A., Blackwell, P., Bronk Ramsey, C., Butzin, M., Cheng, H., Edwards, R., Friedrich, M., Grootes, P., Guilderson, T., Hajdas, I., Heaton, T., Hogg, A., Hughen, K., Kromer, B., Manning, S., Muscheler, R., Palmer, J., Pearson, C., van der Plicht, J., Reimer, R., Richards, D., Scott, E., Southon, J., Turney, C., Wacker, L., Adolphi, F., Büntgen, U., Capano, M., Fahrni, S., Fogtmann-Schulz, A., Friedrich, R., Köhler, P., Kudsk, S., Miyake, F., Olsen, J., Reinig, F., Sakamoto, M., Sookdeo, A., \& Talamo, S. 2020. The IntCal20 Northern Hemisphere radiocarbon age calibration curve (0-55 cal kBP). Radiocarbon, 62.

Spiridonova, E.A. 1996. Zaklyucheniye po rezultatam sporovo-pyltsevogo analiza po stoyanke Zamostje II (raskop 1996 g.) (manuscript). (in Russian)

Spiridonova, E.A.. Aleshinskaya, A.S. 1999. Periodizatsiya neolita-eneolita Evropeyskoy Rossii po dannym palinologicheskogo analiza. Rossiyskaya arkheologiya, 1, 23-33. (in Russian)

Weninger, B., Alram-Stern, E., Bauer, E., Clare, L., Danzeglocke, U., Jöris, O., Kubatzki, C., Rollefson, G., Todorova, H., van Andel, T. 2006. Climate forcing due to the $8200 \mathrm{cal}$ yr BP event observed at Early Neolithic sites in the eastern Mediterranean. Quaternary Research, 66: 401-420. 
Лозовская О.В., ИИМК РАН (Санкт-Петербург, 191186, РФ) Ершова Е.Г.

\section{КАТАСТРОФИЧЕСКИЕ ИЗМЕНЕНИЯ РАСТИТЕЛЬНОСТИ ОКОЛО 8200 Л. НаЗаД И ОЗЁРНЫЕ ПОСЕЛЕНИЯ В ВОЛГО-ОКСКОМ РЕГИОНЕ (На ПрИМере стоянКИ ЗаМостье 2)}

Наиболее значительные изменения в хозяйстве и материальной культуре обществ охотниковсобирателей лесной зоны Восточной Европы накануне распространения керамического производства совпали с похолоданием 8200 cal BР и его последствиями. Мы рассматриваем эти изменения на конкретном примере стоянки Замостье 2, расположенной в Волго-Окском междуречье, используя результаты многолетних междисциплинарных исследований. Результаты наших археологических и палеоэкологических исследований и сравнение с опубликованными данными по рассматриваемому региону показали картину локальных изменений на фоне региональной нестабильности экологической ситуации, а также скачкообразного развития традиций материальной культуры во второй половине 7 - начале 6 тыс. cal BC.

Ключевые слова: Похолодание $8200 \mathrm{cal} \mathrm{BP,} \mathrm{палеоэкологические} \mathrm{изменения,} \mathrm{Верхняя} \mathrm{Волга,} \mathrm{позд-}$ ний мезолит, последние охотники-собиратели, озёрное поселение Замостье 2

Лозовська О.В., Інститут історії матеріальної культури РАН (Санкт-Петербург, Росія) Єршова К.Г. Московський державний університет ім. М.В. Ломоносова, (Москва, Росія); Казанський Федеральний університет (Казань, Росія)

\section{КАТАСТРОФІЧНІ ЗМІНИ РОСЛИННОСТІ БЛИЗЬКО 8200 р. тому I ОЗЕРНI СТОЯНКИ У МЕЖИРІЧЧІ ВОЛГИ ТА ОКИ (на прикЛаді стоянкИ Замостя 2)}

Кліматичні та екологічні зміни завжди прямо чи опосередковано впливали на економічне та соціальне життя первісних спільнот. Однак ретельне вивчення конкретних явищ у житті людських колективів обмежується численними факторами. Перш за все, різною швидкістю і послідовністю природних змін та реакцією людини на них (від швидких рішень до поступової адаптації до нових умов), доступності та точності абсолютного датування, нарешті, від різноманіття та якості інформаційної бази.

Найбільш значні зміни в господарстві та матеріальній культурі суспільств мисливців-збирачів лісової зони Східної Європи напередодні поширення керамічного виробництва збіглися з похолоданням 8200 cal BP і його наслідками. В запропонованій статті ці зміни розглядаються на конкретному прикладі стоянки Замостя 2, розташованої у межиріччі Волги та Оки, використовуючи результати багаторічних міждисциплінарних досліджень. Аналіз решток матеріальної культури в обох шарах доводить, що населення не залишало ці місця протягом «холодної події» 8200 років тому та в наступні часи. Разом з тим, ми спостерігаємо низку культурних, типологічних та технологічних змін, які можуть бути пов'язані як із внутрішнім розвитком, включаючи реакцію на зміну клімату / ландшафту так і з зовнішніми імпульсами. При безсумнівній загальній безперервності економічних стратегій та схожості більшості кістяних і крем'яних знарядь, розглянутий період характеризується щонайменше трьома культурними впливами, які найбільш чітко простежуються в частковій зміні мисливського та рибальського спорядження.

Результати наших археологічних та палеоекологічних досліджень і порівняння з опублікованими даними по окресленому регіону показали картину локальних змін на тлі регіональної нестабільності екологічної ситуації, а також стрибкоподібного розвитку традицій матеріальної культури в другій половині 7 - на початку 6 тис. до нової ери.

Ключові слова: Похолодання 8200 cal BP, палеоекологічні зміни, Верхня Волга, пізній мезоліт, останні мисливці-збирачі, озерне поселення Замостя 2 


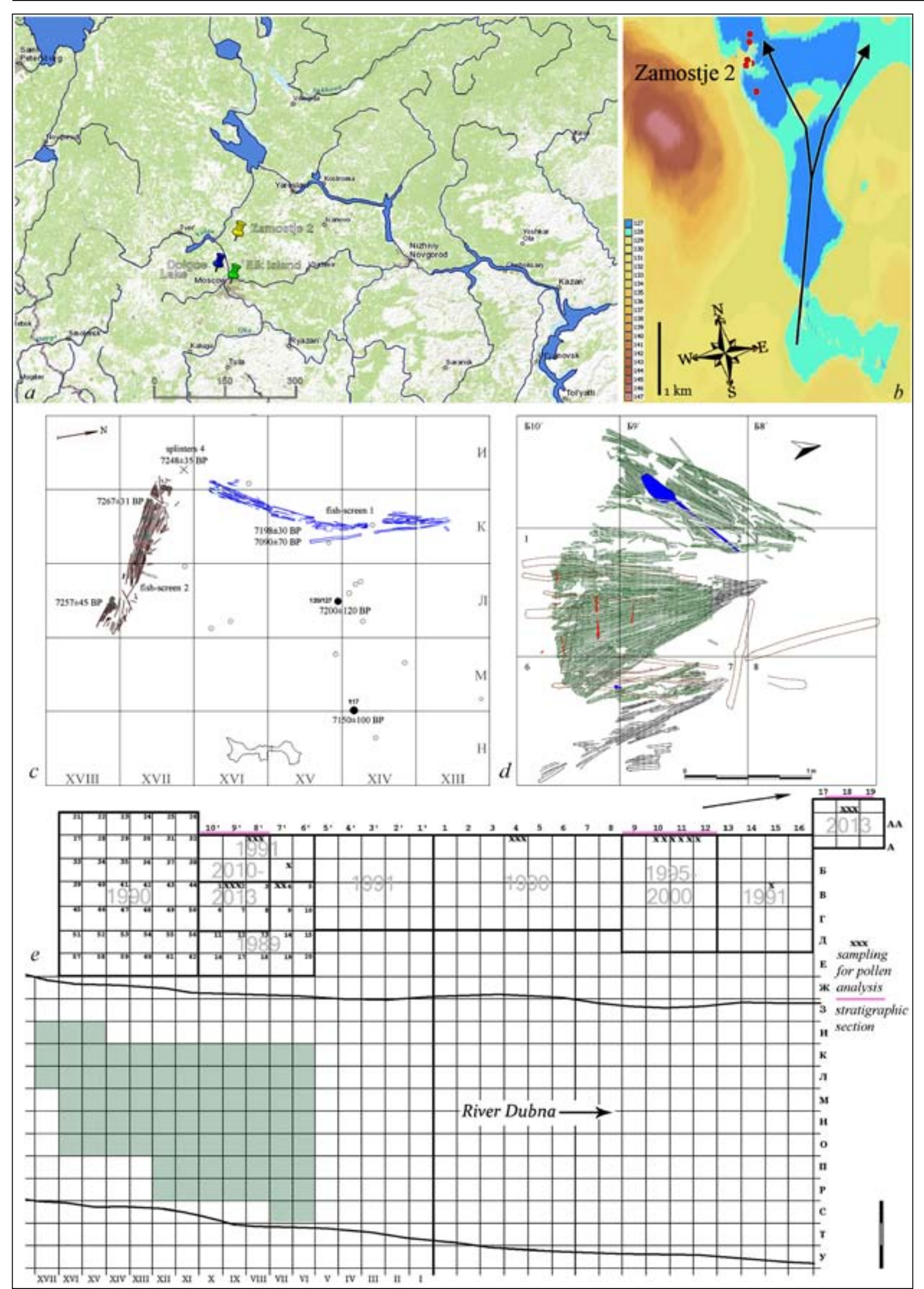

Fig. 1. Zamostje 2. a - Location of the site Zamostje 2, the Losiny Ostrov National Park and Lake Dolgoe; b - paleolandscape reconstruction in area of the site Zamostje 2; c - Late Mesolithic wooden fishing constructions and vertical piles in the underwater part of the site; $d$ - Early Neolithic fish-traps complex; f - excavation scheme of Zamostje 2 (1989-1991, 19952000, 2010-2013) with pollen sampling places 
Zamostje 2 1995-2000

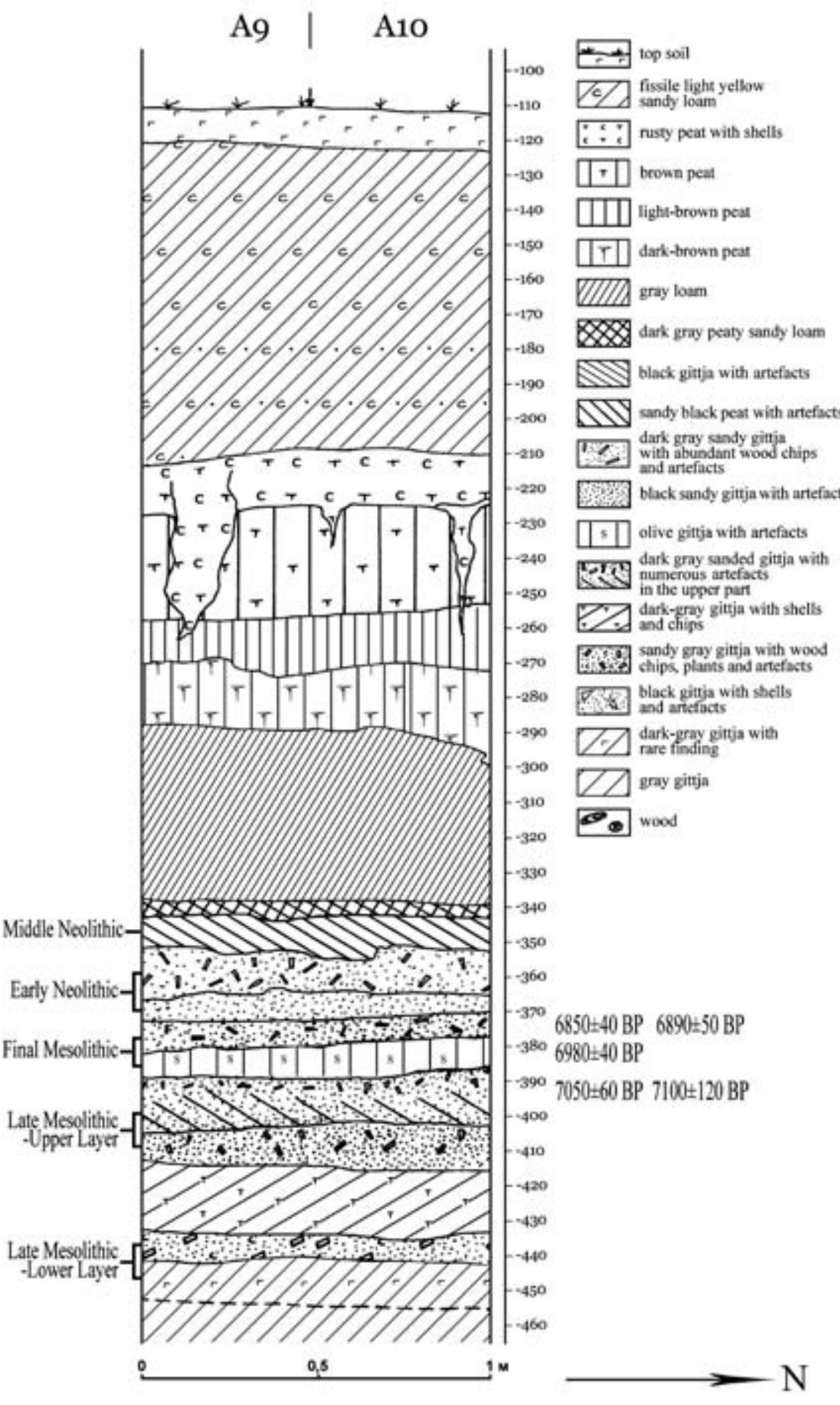

Zamostje 22013

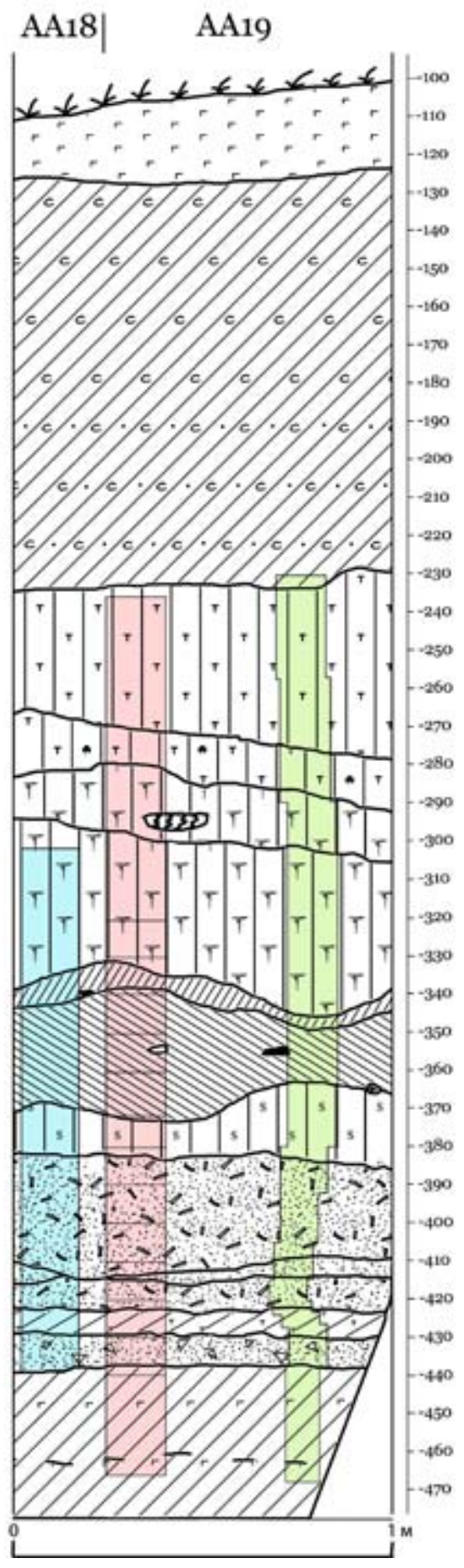

Fig. 2. Zamostje 2. Stratigraphic sections 1995-2000 (A9/A10) and 2013 (AA18), with marked sampling sites (blue column of macrobotany, pink column - 14C, green - pollen) 

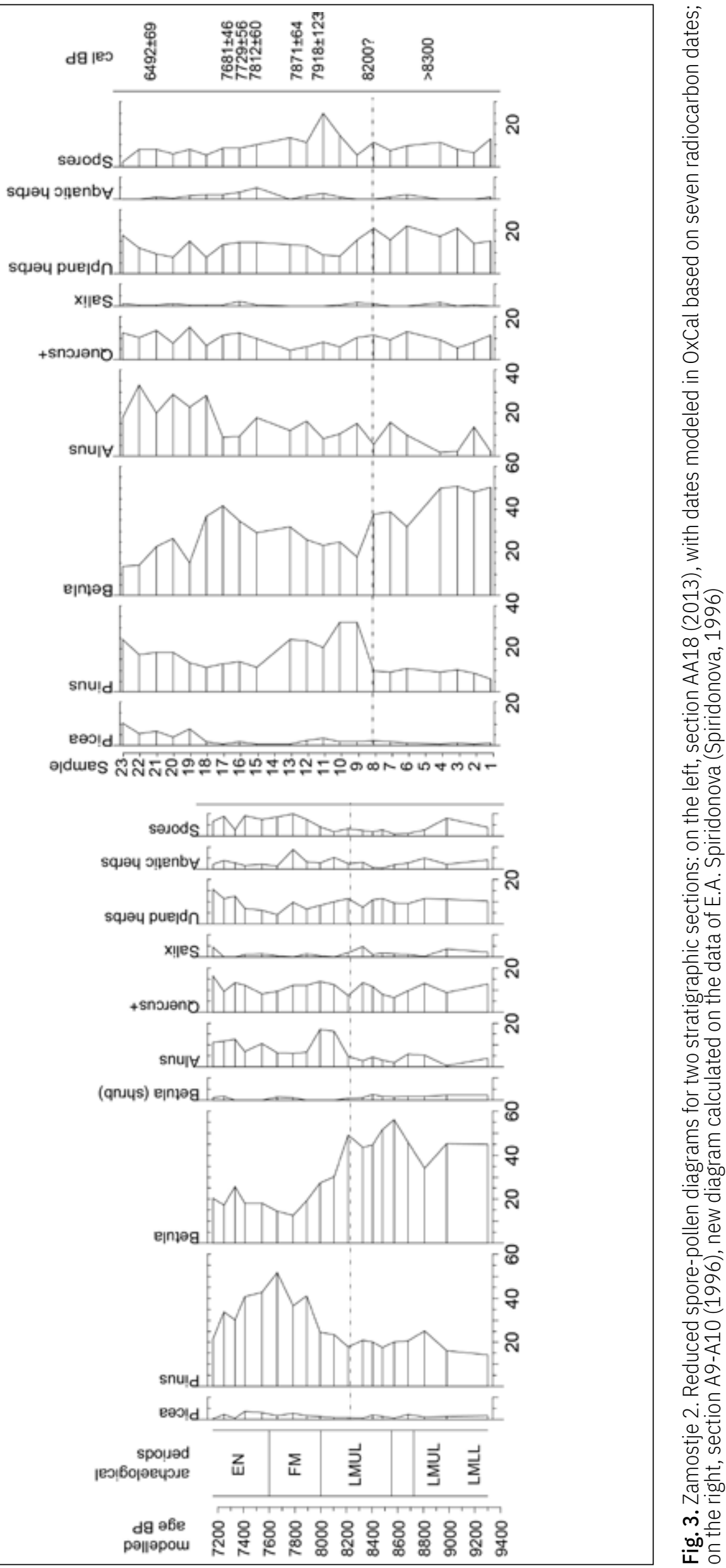


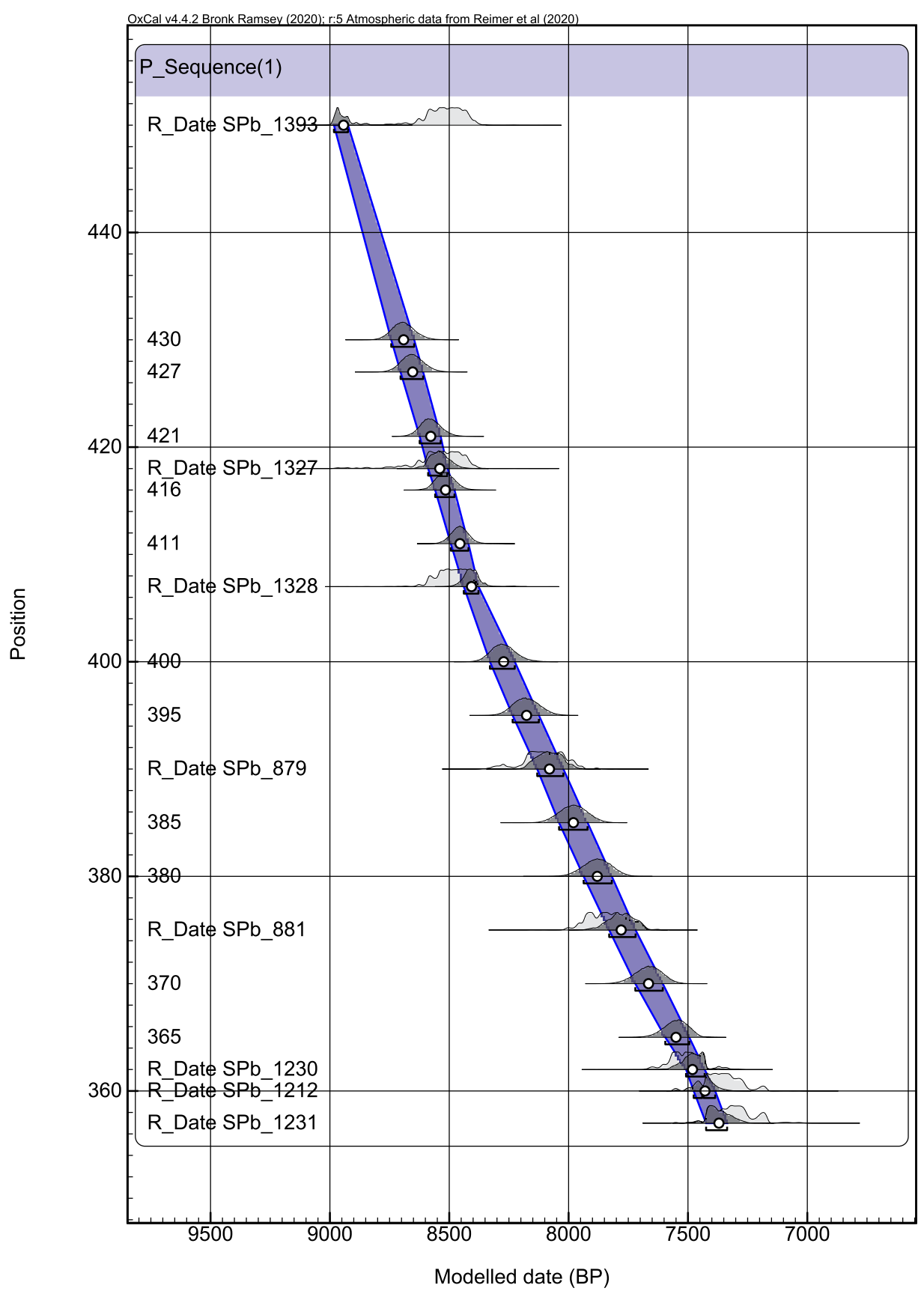

Fig. 4. Zamostje 2. Model of the rate of sediment growth in the section AA18 (2013), built from seven radiocarbon dates in the OxCal program

\section{Zamostje 2, Late Mesolithic Lower Layer}

A

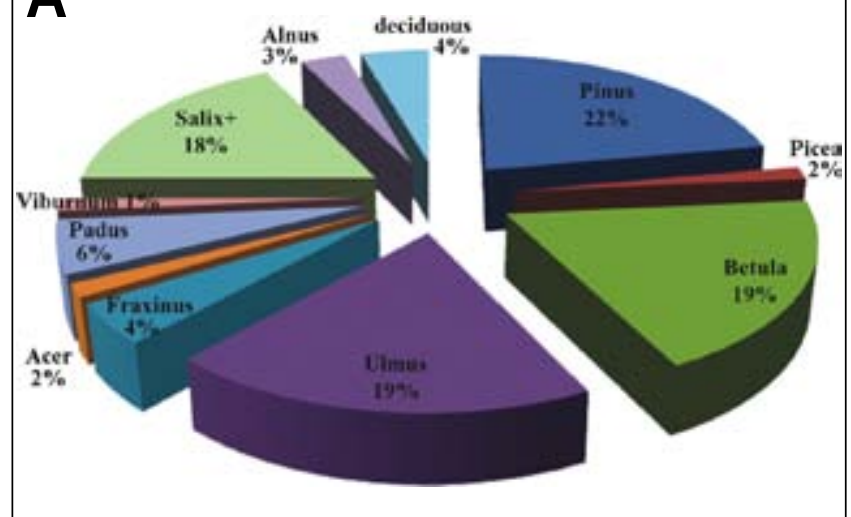

Zamostje 2, Late Mesolithic Upper Layer

B

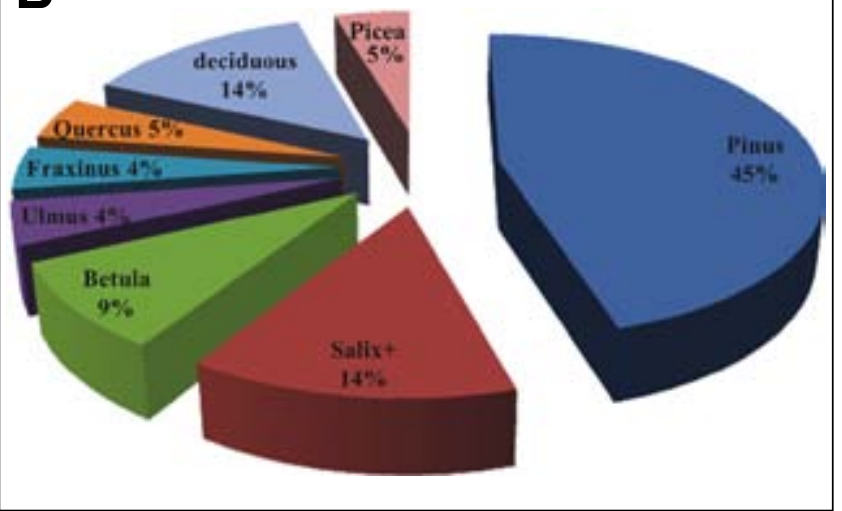

Fig. 5. Zamostje 2. Species of woods used for artefacts of Late Mesolithic layers: A - low layer (LM LL); B - upper layer (LM UL) 


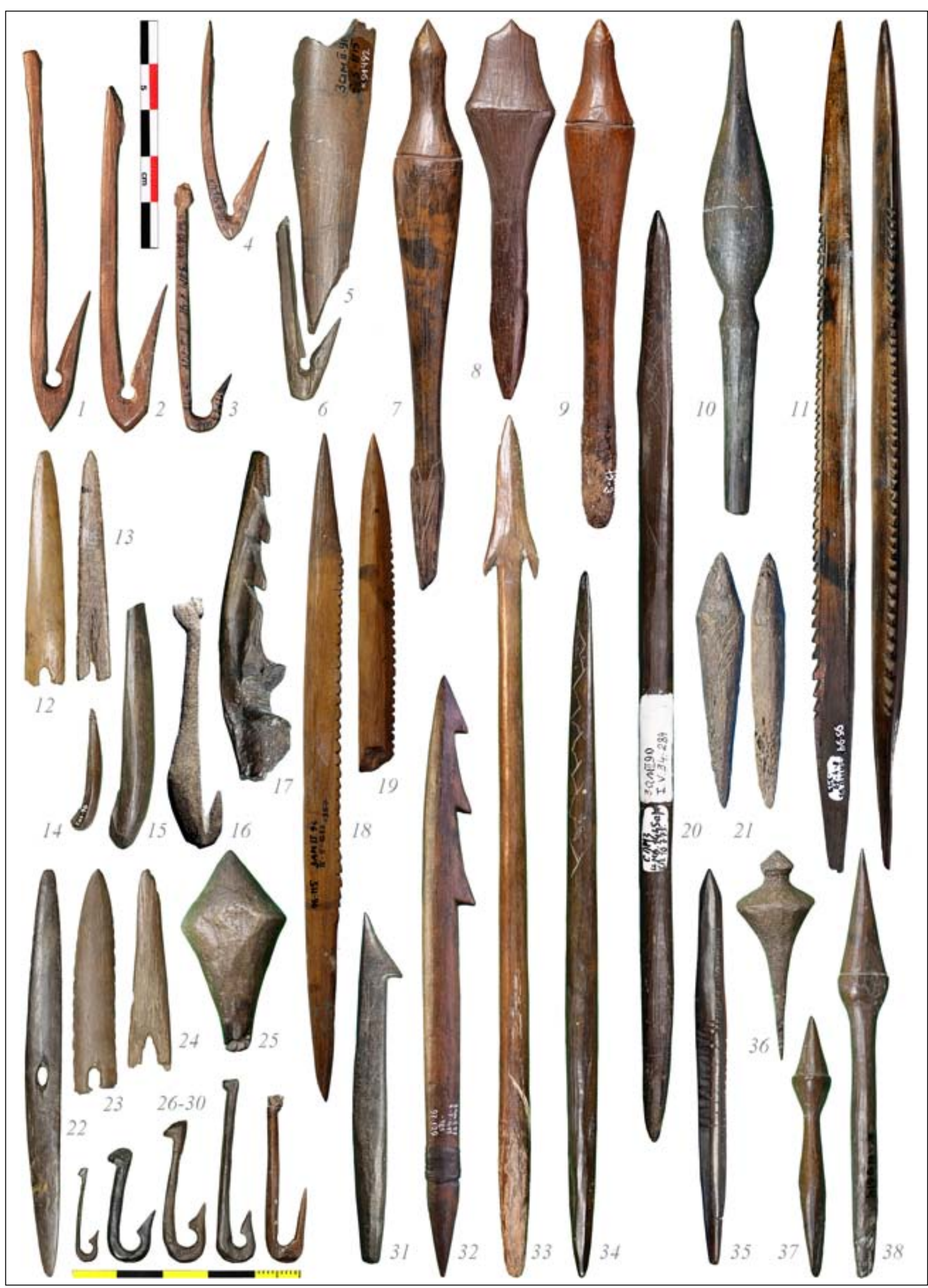

Fig. 6. Zamostje 2. Artefacts from bone and elk antler: EN layer-1-11; FM layer - 12-21; LM upper layer - 22-38. Fishhooks - 1-4, 6, 14-16, 26-30; willow-leaved fishing hooks - 12-13, 22-25, arrowheads - 7-10, 20-21, 25, 33-38; barbed points - 11, 17-19, 31-32 
